\title{
Gill morphology of native brown trout Salmo trutta m. fario experiencing acute and chronic acidification of a brook in Bavaria, FRG*
}

\author{
Theresia Fischer-Scherl, Rudolf W. Hoffmann \\ Institut für Zoologie und Hydrobiologie der Universität München, Kaulbachstraße 37, D-8000 München 22, \\ Federal Republic of Germany
}

\begin{abstract}
Gill morphology of brown trout Salmo trutta $m$. fario inhabiting a periodically acidified brook in the eastern part of Bavaria, Federal Republic of Germany, was studied by light and electron microscope. Gills from brown trout caught at a snowmelt period ( $\mathrm{pH} 4.9$; Al $0.8 \mathrm{mg} \mathrm{l}^{-1}$ ) were characterized by an increase in mucous cells and excessive mucus production which caused the fusion of secondary lamellae. Gills from brown trout sampled from the same brook in a dry period in September

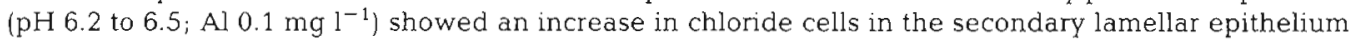
and an attachment of opposing cells, epithelial or chloride cells in the respiratory epithelium of neighbouring secondary lamellae.
\end{abstract}

\section{INTRODUCTION}

The acidification of inland waters and soil has been recognized as a serious problem in parts of Canada, the USA, Scandinavia and the UK (Last et al. 1980). In the last few years acid precipitation has also become a primary environmental problem in the Federal Republic of Germany (FRG) (Wieting et al. 1984, Lehmann et al. 1985). How acid precipitation affects an area depends on the vegetation and on the physical and chemical nature of the soils and bedrock (Last et al. 1980, Mason \& Seip 1985). In areas such as the Bavarian Forest ('Bayerischer Wald'), with no appreciable amount of carbonate-bearing materials and slow chemical weathering, the neutralizing capacity of soil and water is low and does not allow complete neutralization of acid runoff. The acid input causes the $\mathrm{pH}$ of the water to decrease while aluminium and other metals are mobilized (Mason \& Seip 1985).

Acidification produces profound changes in the biota of aquatic ecosystems and has far-reaching consequences on all trophic levels of aquatic life (Muniz 1981, Bauer \& Fischer-Scherl 1987). One of the consequences, the depletion of fish stocks in brooks, has - Dedicated to Professor Dr M. Ruf, University of Munich, on
his 60 th birthday recently become increasingly evident in some regions of the FRG (Fischer-Scherl et al. 1986).

In this article we report on the gill morphology of a native brown trout population experiencing chronic and periodically acute acidification of a brook. In contrast to previous studies, which mainly discussed laboratory findings, we present the results of a field investigation, which provides the opportunity to consider, under natural conditions, the synergism of a variety of potentially toxic factors and to evaluate their acute and long-term pathological effects on gills.

\section{MATERIAL AND METHODS}

Study area. The study area comprised the basementcomplex area of Eastern Bavaria - the Bavarian Forest - near the mountain of Arber (1456 m). The region is very susceptible to acid precipitation because of the geochemistry of surficial sediments and bedrocks which are mainly composed of slow-weathering granites and gneisses. Brooks in this area are oligotrophic, show low conductivity $\left(60 \mu \mathrm{S} \mathrm{cm}^{-1}\right.$, most of them less than $40 \mu \mathrm{S} \mathrm{cm}^{-1}$ ), low buffering capacity and $\mathrm{pH}$ levels ranging from more than $\mathrm{pH} 6$ to $\mathrm{pH} 3.7$. The vegetation is typical for the region, consisting mainly of coniferous forest with a mixture of spruces and firs. The 
Table 1. Water analysis data from acidified and control brook

\begin{tabular}{|c|c|c|c|c|}
\hline & \multicolumn{2}{|c|}{ Acidified brook } & \multicolumn{2}{|c|}{ Control brook } \\
\hline & $\begin{array}{l}\text { April snowmelt } \\
\text { period. 'Acute } \\
\text { acid exposure' }\end{array}$ & $\begin{array}{l}\text { September dry } \\
\text { period. 'Chronic } \\
\text { acid exposure' }\end{array}$ & $\begin{array}{l}\text { April snowmelt } \\
\text { period }\end{array}$ & $\begin{array}{l}\text { September } \\
\text { dry period }\end{array}$ \\
\hline $\mathrm{pH}$ & 4.9 & $6.2-6.5$ & 6.2 & 6.5 \\
\hline $\mathrm{Ca}\left(\mathrm{mg} \mathrm{l} 1^{-1}\right)$ & 1.75 & $2.2-3.3$ & 2.25 & 4.7 \\
\hline $\mathrm{Mg}\left(\mathrm{mg} \mathrm{l}^{-1}\right)$ & 0.8 & $0.9-1.2$ & 0.9 & 1.1 \\
\hline $\mathrm{Al}\left(\mathrm{mg} \mathrm{l}^{-1}\right)$ & 0.8 & 0.1 & 0.01 & 0.01 \\
\hline Conductivity $\left(\mu \mathrm{S} \mathrm{cm}^{-1}\right)$ & 41 & $34-36$ & 31 & 38 \\
\hline Water temperature $\left({ }^{\circ} \mathrm{C}\right)$ & 5 & $5.0-8.5$ & 5.5 & 8.2 \\
\hline
\end{tabular}

number of deciduous trees is insignificant. The upper part of the brook was investigated, where there is no fishing activity, houses are far off and the brook is not polluted by domestic or agricultural sewage. A dam prevents fish from leaving or entering the upper course of the stream. pH levels vary from 4.9 in spring to 6.5 in summer and autumn (Table 1).

A second brook in the same region was used as a control. This brook has a comparable mineral content (soft water), but does not experience acidification (Table 1).

Methods. Brown trout Salmo trutta m. fario were caught by electrofishing in April (10 individuals) and in September (13). The examined fish were aged between 2 and 4 yr. They were killed with $0.007 \%$ tricaine methane-sulfonate (MS 222; Sandoz). Gills were immediately taken, fixed in $5 \%$ buffered formalin and embedded in Paraplast ${ }^{\otimes}$. Sections 5 um thick were stained with hematoxylin eosin $(\mathrm{H} \& \mathrm{E})$, methylene blue, Giemsa's technique and periodic acid-Schiff (PAS) reaction. The plane of section is shown in Fig. 1.
Tissue samples for transmission electron microscopy (TEM) were fixed in $6.25 \%$ phosphaie-buffered glutaraldehyde $(\mathrm{pH} 7.4)$ for $2 \mathrm{~h}$, postfixed in $1 \%$ buffered $\mathrm{OsO}_{4}$ for $2 \mathrm{~h}$, dehydrated in a graded acetone series and finally embedded in Epon $812^{\circledR}$. Semi-thin sections were stained with toluidine blue; ultrathin sections were stained with uranyl acetate and lead citrate and examined in a Zeiss transmission electron microscope (EM 109) at $80 \mathrm{kV}$.

Trout (15 in April, 15 in September) from the control brook served as reference fish.

Total aluminium content (Al) of the water samples was determined by atomic absorption spectroscopy. To study the Al accumulation in gills, tissue samples were dissolved in concentrated $\mathrm{HNO}_{3}$ at room temperature and analysed by an ICP-AES analyser (965 JarellASH).

Additionally, samples of all fish were routinely examined by virological, bacteriological and parasitological standard methods.

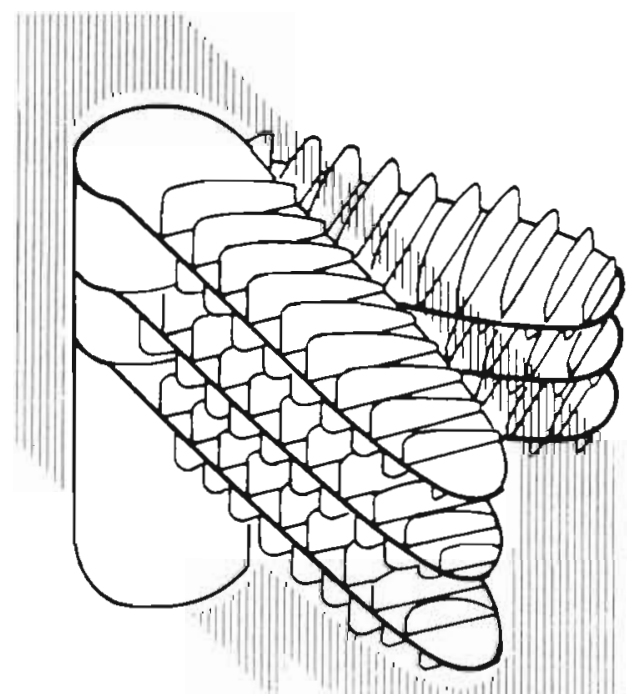

Fig. 1. Salmo trutta. Plane of section through the gills

\section{RESULTS

\section{Gill morphology of reference fish}

Macroscopic lesions were seen neither in the gills of brown trout from the acidic nor in those from the nonacidic control brook. Gills of controls (Fig. 2) exhibited fairly normal microscopic features comparable to those of other fish species, described by Morgan \& Tovell (1973), Karlsson (1983) and Fischer (1984). Each gill arch bears a double row of primary lamellae (holobranch) positioned alternately. Each primary lamella carries secondary lamellae consisting of a network of interconnecting blood lacunae, which are lined by pillar cell flanges. A distinct basement membrane separates pillar cells from the double-layered respiratory epithelium. Extracellular spaces between the 2 layers of the respiratory epithelium were hardly detectable. Occasionally 2 or 3 mucous cells could be 
detected in the respiratory epithelium, as well as the 'light' and 'dark' form of chloride cells. The majority of mucous cells in the gills of control brown trout were localized in the interlamellar crypts, at the anterior dorsal and posterior ventral edges and at the distal end of primary lamellae. Gills from reference brown trout caught in April did not differ from those gills of reference brown trout caught in September Fusion of lamellae was never seen in the gills of control brown trout

\section{Morphology of gills sampled in April at acute acid exposure}

The most remarkable feature of gills from brown trout caught in April ( $\mathrm{pH} 4.9, \mathrm{Al} 0.8 \mathrm{mg} \mathrm{l}^{-1}$ ) during a snowmelt episode, was the increase in number of mucous cells (Fig. 3) and the excessive mucus production (Fig. 4) in the respiratory epithelium. In contrast to reference gills and to those sampled in the same brook in September at the dry period, mucous cells regularly occurred in the respiratory epithelium of gills sampled at $\mathrm{pH}$ 4.9. PAS-stained sections revealed clogging of the interlamellar spaces, either due to mucous hypersecretion or through the attachment of mucous cells of neighbouring secondary lamellae (Figs. 4 and 5). Layers of mucous substances covered the cells of the respiratory epithelium. Additionally the interlamellar spaces between the 2-layered respiratory epithelium were extended and/or the respiratory epithelium was lifted from the basement membrane (Fig. 6). In electron micrographs chloride cells exhibited malformed aggregated mitochondria with increased electron density and cristae placed to the periphery. Aggregations of apparently degenerating mitochondria and endoplasmic reticulum (ER) were limited by a membrane (phagolysosome) (Fig. 7). TEM also revealed that the cytoplasm of some chloride cells was highly vacuolated and contained distended fragments of ER (Fig. 8). In a few respiratory epithelial and chloride cells the nucleus was undergoing karyorhexis followed by karyolysis.

\section{Morphology of gills sampled in September at chronic acid exposure}

The morphological features of gills sampled in September ( $\mathrm{pH} 6.2$ to 6.5 , Al $0.1 \mathrm{mg} \mathrm{l}^{-1}$ ) essentially differed from those studied during the snowmelt period at $\mathrm{pH}$ 4.9. Mucous cells mainly resided in interlamellar crypts of the primary lamellae with only 1 to 2 mucous cells occasionally appearing in the respiratory epithelium. No fusion due to mucus secretion occurred. The most striking feature however, was the increase of chloride cells, in number as well as in size, particularly in the respiratory epithelium (Figs. $9 \mathrm{a}, \mathrm{b}$ and 10 ). Up to $70 \%$ of the cells in the respiratory epithelium were represented by chloride cells. They were situated side by side, usually in direct contact with the external medium. Apical surfaces of chloride cells were large with many microvilli-like cytoplasmatic extensions. Flanges of respiratory epithelial cells passing between neighbouring chloride cells were in contact with the external medium covering parts of the apical surfaces of the chloride cells as a small rim (Fig. 10).

In gills sampled at $\mathrm{pH} 4.9,3$ or more secondary lamellae were fused caused by the excessive mucus production and hyperplasia of mucous cells. Gills sampled at $\mathrm{pH} 6.2$ to 6.5 also showed fusions, but this process occurred by simple apposition of adjacent lamellae to each other due to the attachment of long microvilli-like cytoplasmatic extensions either to chloride cells or to epithelial cells (Figs. 11 and 12). These cytoplasmatic protrusions met in a tight-junction-like contact (Fig. 13). Fusion of 1 or 2 cells in the middle part or distal ends of 2 adjacent secondary lamellae was a dominant feature. In secondary lamellae, displaying these tight contacts, widened extracellular spaces appeared beneath the cells involved. Distended tubules, lysosomes and residual bodies with myelin figures (Fig. 14) were most frequently seen in chloride cells and respiratory epithelial cells, which participated in contacts between adjacent secondary lamellae, while most other chloride cells exhibited fairly normal structures (Fig. 15).

\section{DISCUSSION}

This study clearly demonstrates that gill morphology varies according to changes in water chemistry. All examined fish were free of bacterial and viral diseases and parasites that could damage gill epithelium were not detected

Gills, the organs involved in the physiological process of gas transfer and acid-base regulation (Randall et al. 1982), as well as osmotic and ionic regulation (Eddy 1982), are considered to be the primary target organ in cases of fish deaths in acidified water (Muniz \& Leivestad 1980a). The described gill lesions at pH 4.9 and $\mathrm{Al} 0.8 \mathrm{mg} \mathrm{l}^{-1}$ can be attributed to a synergistic effect of low $\mathrm{pH}$, low mineral content and the accumulation of metal ions in the water

In gill tissue of brown trout caught at $\mathrm{pH} 4.9$ a higher amount of Al was found compared to gills sampled at pH 6.2 to 6.5 (Fischer-Scherl et al. unpubl.). Thus it can be concluded that, in addition to the low $\mathrm{pH}$, the high amount of $\mathrm{Al}$ is probably responsible for the signs of degeneration observed in the respiratory epithelium. 

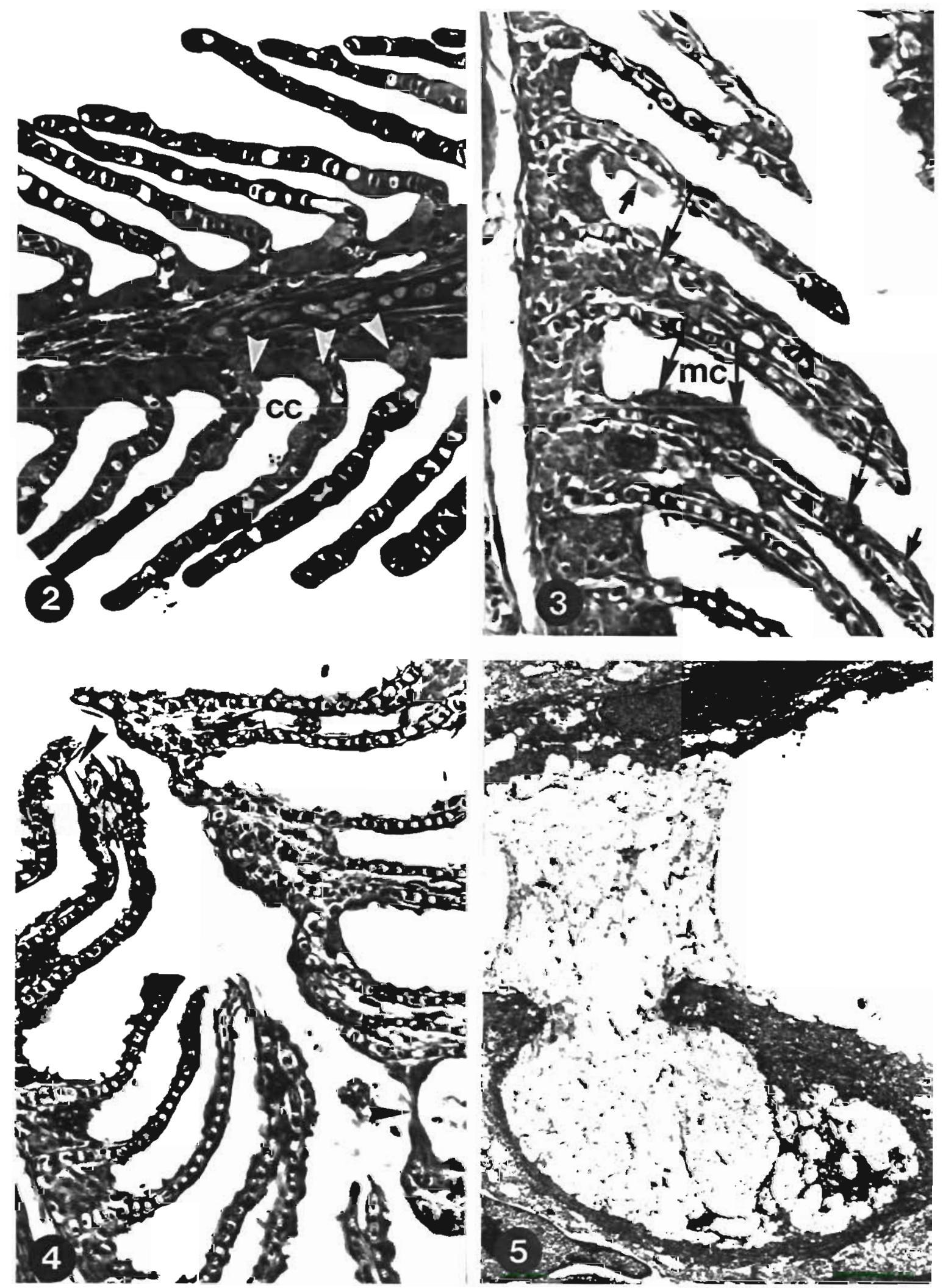

Figs. 2 to 4. (For Fig. 5, see legend opposite.) Salmo trutta. Fig. 2. Light micrograph of longitudina. Epon section of secondary lamellae of gills of brown trout from control brook ( $\mathrm{pH} 6.2, \overline{\mathrm{Al}} 0.01 \mathrm{mg} \mathrm{l^{-1 }}$ ) showing normal appearance. Chloride cells (cc) are mainly restricted to the interlamellar epithelium. Toluidine blue, $\times 240$. Figs. 3 and 4 . Light micrographs of gills of brown trout caught at a snowmelt period (acute acid stress; $\mathrm{pH} 4.9$, Al $0.8 \mathrm{mg}^{-1}$ ). Fig. 3. Mucous cells (mc; long arrows) proliferate in the respiratory epithelium. Secondary lamellae are fused and respiratory epithelium is detached from the basement membrane (short arrows). PAS, $\times 280$. Fig. 4. Fusion of secondary lamellae caused by the excessive production and accumulation of mucous 


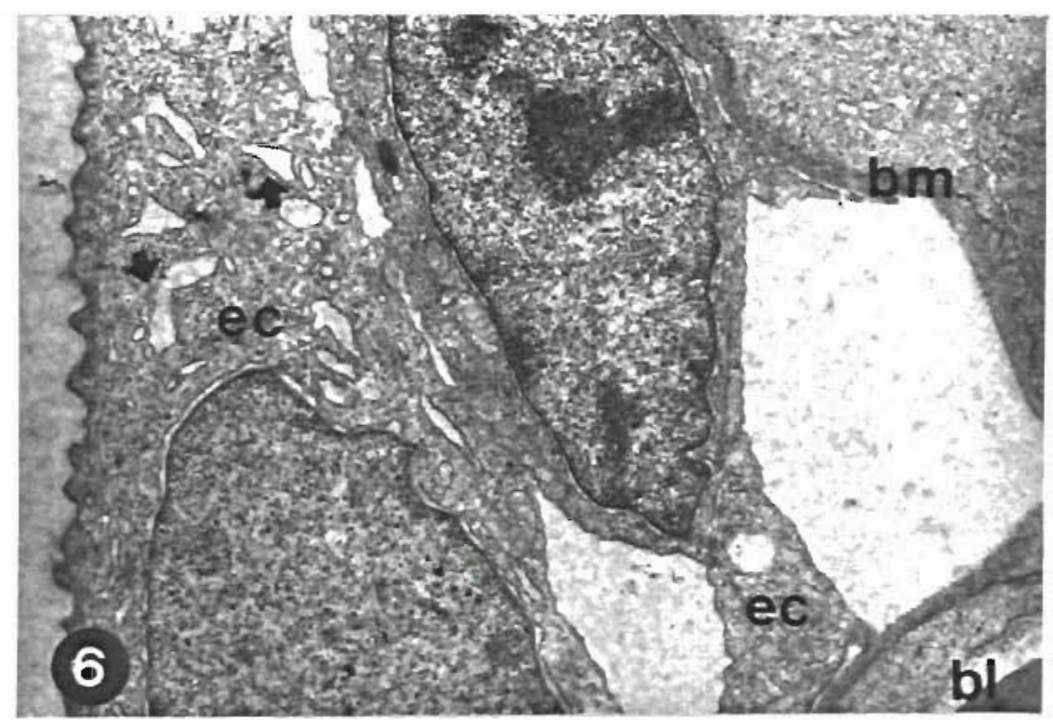

Figs 5 to 8 . Salmo trutta. Transmission electron micrographs of gills of brown trout from the acidified brook at $\mathrm{pH} 4.9$ and $\mathrm{Al} 0.8 \mathrm{mg} \mathrm{l}^{-1}$ Fig. 5 (opposite). A mucous cell. Mucus attaches to an epithelial cell of the adjacent lamella. $\times 5000$. Fig. 6 . Note extended intercellular spaces between epithelial cell (ec) and basement membrane (bm) and between epithelial cells of the respiratory epithelium bl: blood lacuna; arrows: dilation of endoplasmic reticulum (ER). $\times 8300$. Fig. 7 . Detail of an apparently degenerating chloride cell with aggregation of electron-dense mitochondria (m) segregated by a membrane. $\times 33000$. Fig. 8. Chloride cells showing vacuolated cytoplasm (va), lytic mitochondria (long arrows) and dilation of ER (short arrows) $\times 8200$
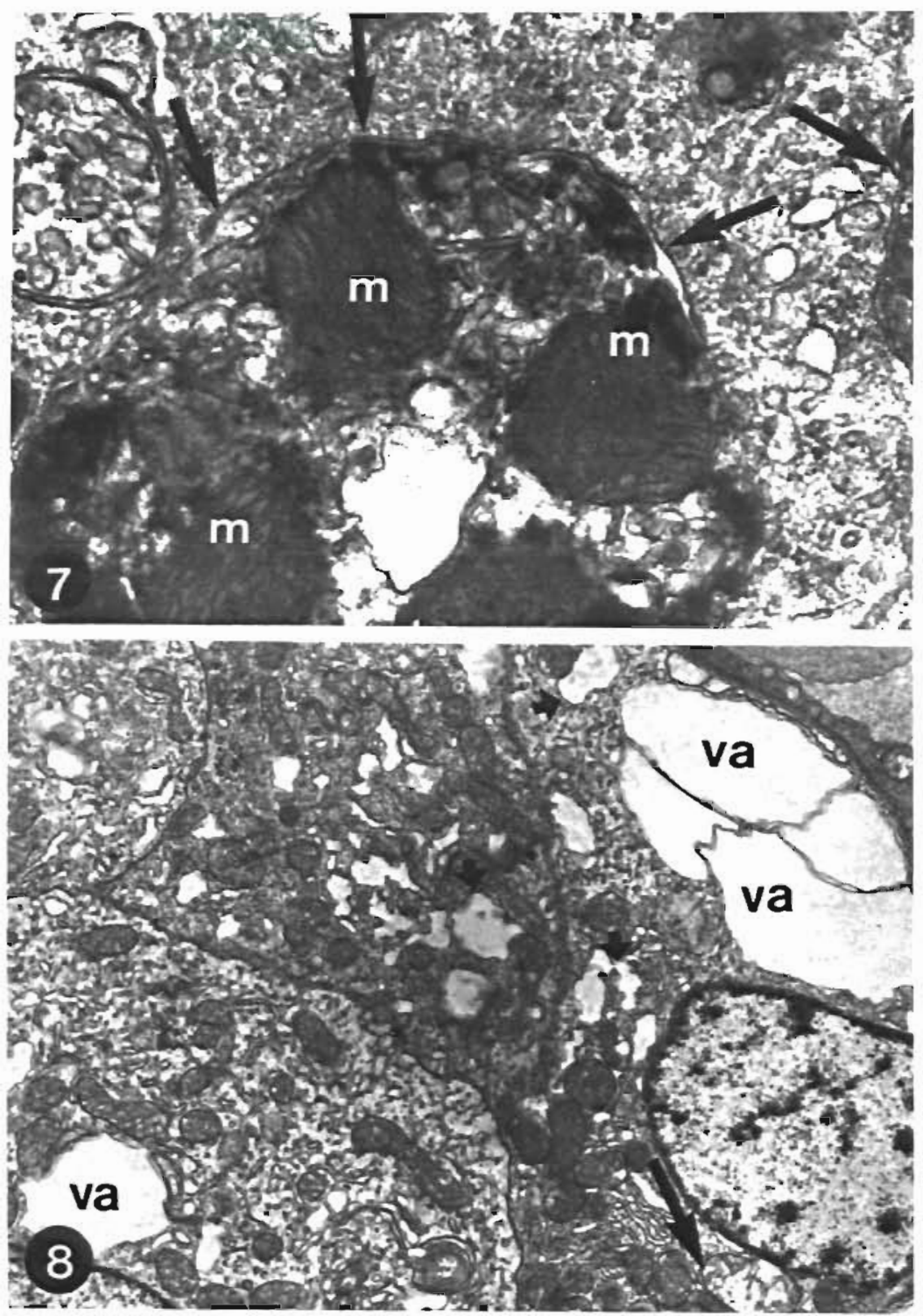

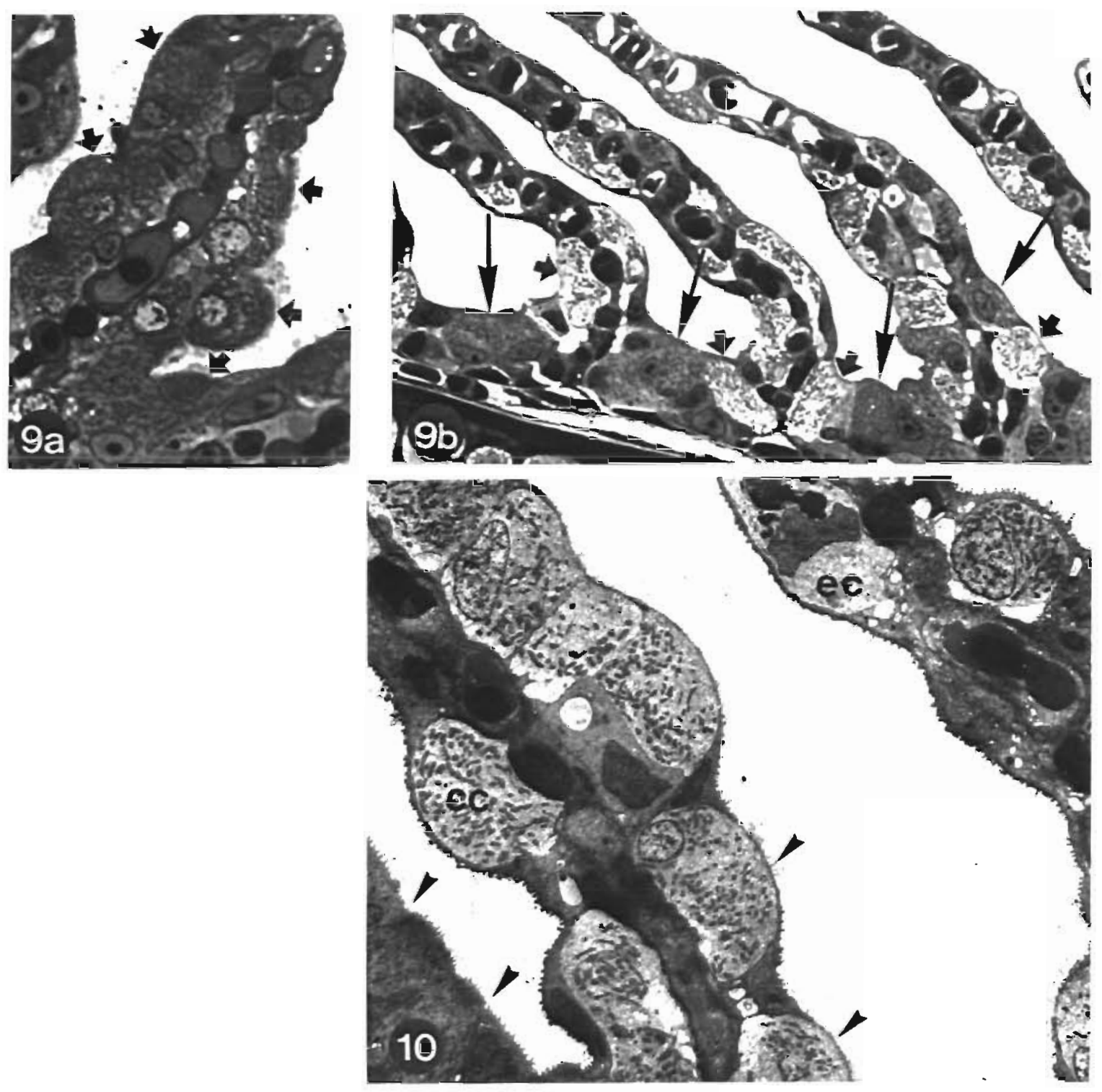

Figs. 9 to 11. Salmo trutta. Gills of trout sampled in September (chronic acid stress; pH 6.2 to 6.5, Al $0.1 \mathrm{mg} \mathrm{l}^{-1}$ ). Fig. 9 (a, b). Light micrograph showing (a) enormous proliferation of domeshaped chloride cells in the respiratory epithelium (semithin section; toluidine blue, $x$ 600); (b) light (short arrows) and dark (long arrows) form of chloride cells are easily distinguishable (semithin section; coluidine blue, $x$ 480). Fig. 10. Transmission electron micrograph (TEM) showing increase in chloride cells (cc) in the secondary lamellae, epithelial cells (ec) with picnotic masses and chloride cells with large apical surfaces charactenzed by many microvilli-like cell extensions (arrows). $\times 1500$. Fig. 11. TEM showing chloride cell (cc) with its cytoplasmic extensions closely adhering to the epithelial cell $(\mathrm{ec})$ in the region of the marginal channel (mc) of adjacent secondary lamellae. $x$

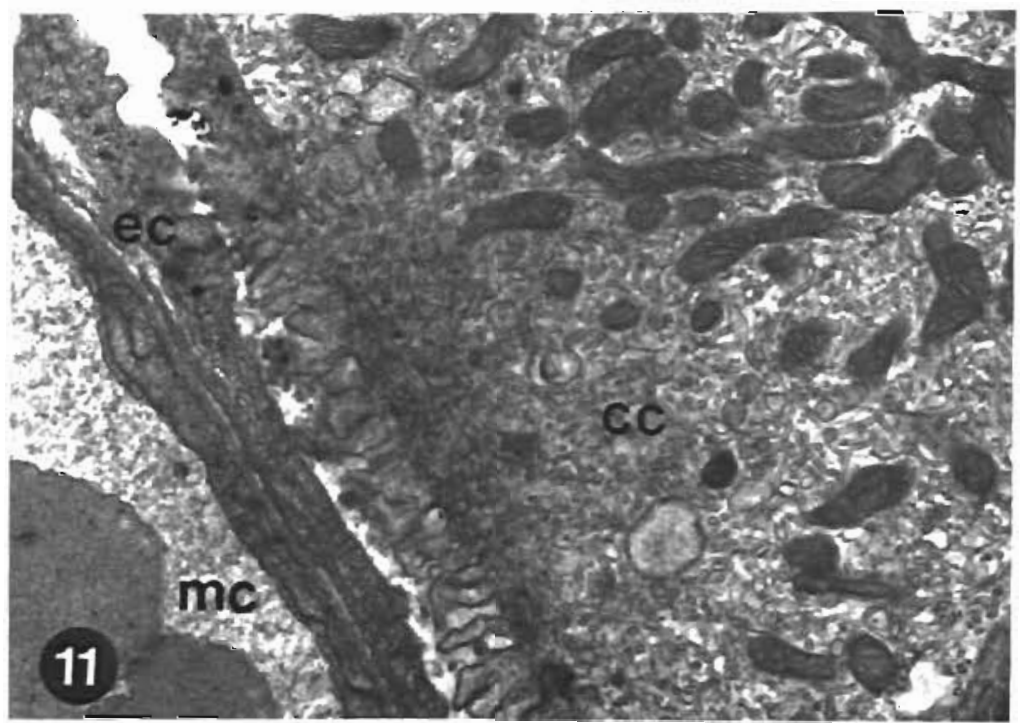



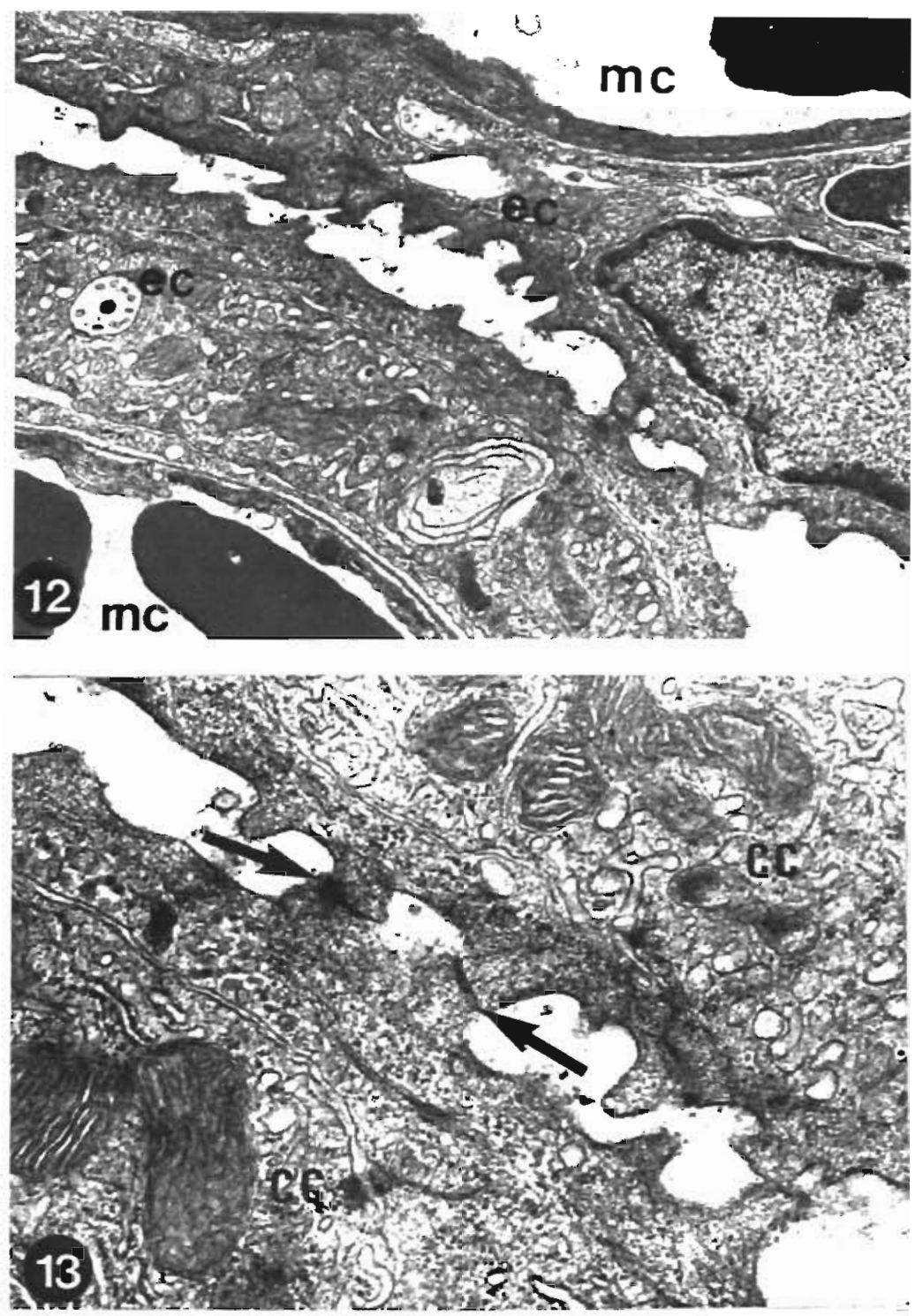

Figs. 12 to 15. Salmo trutta. Transmission electron micrographs of gills of trout sampled in September ( $\mathrm{pH} 6.2$ to $6.5, \mathrm{Al} 0.1 \mathrm{mg} \mathrm{l}^{-1}$ ). Fig. 12. Adhesion of epithelial cells (ec) at the marginal channels $(\mathrm{mc})$ of adjacent serondary lamellae $\times 13900$. Fig. 13. Attachment of 2 chloride cells (cc) exhibiting close tight-junction-like cell connections (arrows). $\times 25900$. Fig. 14. Detail of chloride cell participating in an attachment. Lysosomal structures, myelin figures and dilated tubules ( $t$ ) can be seen. $x$ 33 000. Fig. 15. Essentially normal appearance of chloride cell; numerous mitochondria (m) are intermingled with cytoplasmir tubular network ( $t$ ). The cell's surface is characterized by Iong microvilli-like cytoplasma extensions. $x$ 10750
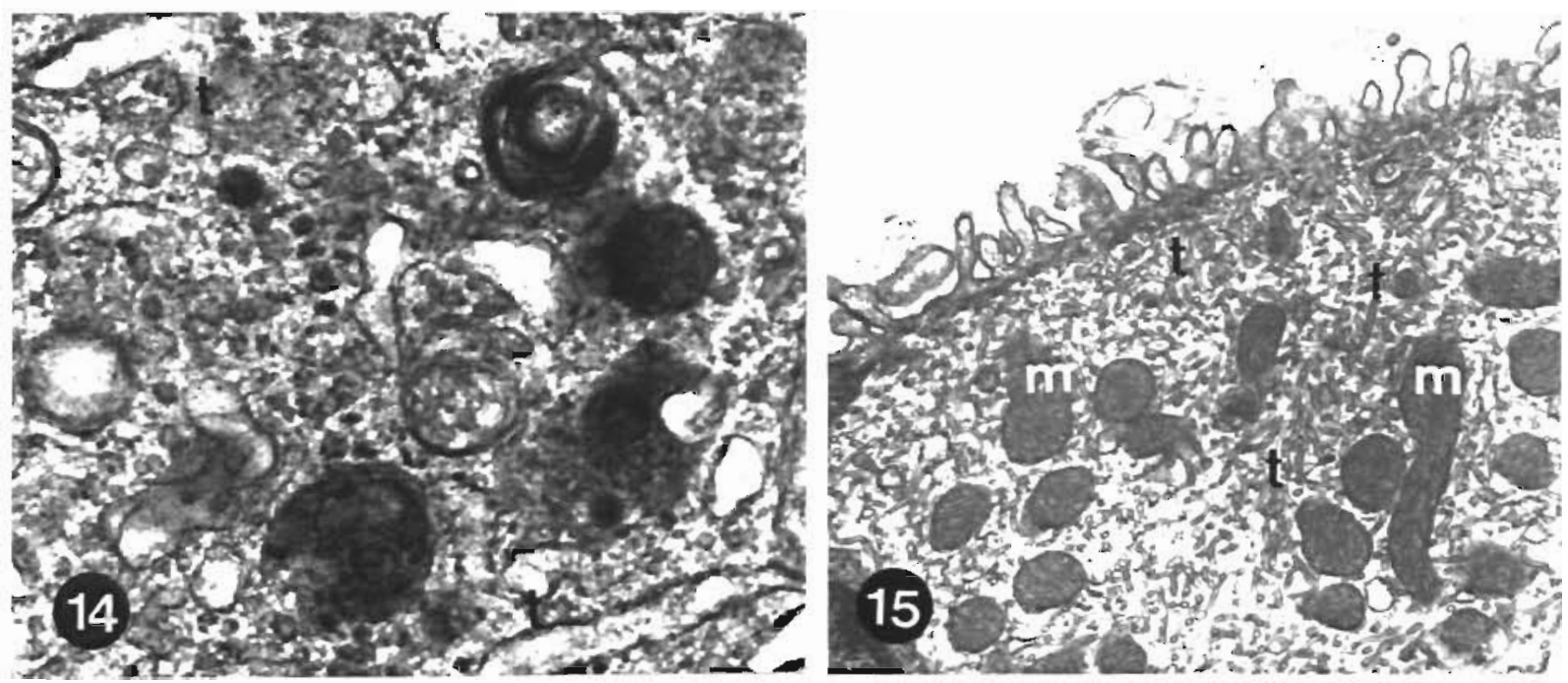
Similar observations and conclusions were also made by Karlsson-Norrgren et al. (1986) in laboratory experiments after exposing brown trout to water at pH 5.5 and an $\mathrm{Al}$ concentration of $500 \mu \mathrm{g} \mathrm{l}^{-1}$ for $3 \mathrm{wk}$.

In a laboratory experiment Daye \& Garside (1976) noticed hypertrophied mucous cells and excessive mucus production after they had exposed brook trout Salvelinus fontinalis to water of $\mathrm{pH}$ 5.2. Muniz \& Leivestad (1980a) observed macroscopically visible mucus secretion and clogging of gills of brown trout at a pH of 4.5 to 4.9 , after they had added $\mathrm{Al}_{2}\left(\mathrm{SO}_{4}\right)_{3}$ to soft brook water They attributed this phenomenon to the presence of Al. According to Mallat (1985) hypersecretion of branchial mucous cells is a lesion most frequently associated with heavy metals. Mucins, which are often polyanions, may trap metal cations and plevent toxicants from crossing the gill epithelium (Lock \& van Overbeeke 1981, Pärt \& Lock 1983). A similar mechanism may exist in the case of Al. But fused secondary lamellae, thick layers of mucus covering the respiratory lamellae and extended intercellular spaces reduce gas exchange at the gills (Hughes \& Morgan 1973, Ultsch \& Gros 1979). These pathological alterations, as well as degenerative features of the cells in the respiratory epithelium, probably represent the morphological base for pathological effects or failure in electrolyte regulation and gas exchange described in various fish species exposed to acidified water (Packer 1979, Muniz \& Leivestad 1980b, Rosseland 1980, Ultsch et al. 1981, Mckeown et al. 1985).

The increase of chloride cells in number as well as in size was the most obvious and constant characteristic in gills sampled at pH 6.2 to 6.5 (chronic acid stress). This phenomenon is well documented and has been described in various fish species under different conditions: adaptions to low pH levels (Leino \& McCormick 1984), influence of stress (Peters \& Hong 1985), elevated Al concentration (Chevalier et al. 1985, KarlssonNorrgren et al. 1986) and ionic challenge in hard and soft water (Karnaky 1980, Fischer 1984, Laurent et al. 1985). According to Mallat (1985) the increase of chloride cells has to be considered largely non-specific in nature and may primarily represent stereotyped physiological reactions. As several synergistic factors have to be considered in our field study, the effects observed on chloride cells could be interpreted here as a result of chronic stress from both elevated concentration of $\mathrm{Al}$ and radically fluctuating $\mathrm{H}^{+}$ion concentration during heavy rain.

Daoust et al. (1984) observed similar close contacts between adjacent lamellae when they exposed rainbow trout Salmo gairdneri to acutely lethal aqueous concentrations of inorganic mercury and copper. They suggested that the presence of heavy metal ions may result in an alteration of the charge of glycoproteins coating the lamellae and thus favors attractions between cells of adjacent lamellae. Additionally, low $\mathrm{pH}$, as in our case, could intensify the attraction between secondary lamellae

Telangiectasiasis in the gills was not observed in our investigation. Chevalier et al. (1985) described a severe congestion of blood spaces by erythrocytes in the secondary lamellae of brook trout from acidified lakes. They attributed these lesions to circulatory anomalies. Unfortunately they did not mention how they killed the fish, as telangiectasiasis is well documented after killing fish with a blow on the head.

In this study we demonstrated that gills exhibit distinct morphological features according to different water regimes in an acidified brook at different times. It was the purpose of this study to provide field observations in natural running waters, because so far most papers on this subject have described experiments under laboratory conditions or under more stagnant water conditions in lakes. Muniz \& Leivestad (1980a) have however shown that low $\mathrm{pH}$ is less toxic for fish in laboratory experiments and the same $\mathrm{pH}$ is far more toxic for fish when they are in the field.

Acknowledgements. This study was supported by the Bavarian Ministry for Regional Planning and Environmental Protection. We are greatly indebted to the staff of the Institute for Zoology and Hydrobiology for their help in routine diagnostics, Drs H. Miller and G. Merk for their support in electrofishing and their valuable field assistance, and Miss B. Klumpp and Mrs S. Friedrich for their technical. assistence. We also thank Mrs G. Stadier for typing the manuscript and Mr $\mathrm{H}$. Seibt for the help in processing the photomicrographs. Our thanks are extended to Drs A. Hamm and P. Schmitt, Bayer Landesanstalt für Wasserforschung, for providing water analysis

\section{LITERATURE CITED}

Bauer, J., Fischer-Scherl, T. (1987). Biologische Untersuchungen zur Gewasserversauerung an nordostbayerischen Fließgewässern. Fischer und Teichwirt 7: 216-222

Chevalier, G., Gauthier, L., Moreau, G. (1985). Histopathological and electronmicroscopic studies of gills of brook trout Salvelinus fontinalis, from acidified lakes, Can. J. Zool. 63: 2062-2070

Daoust, P. Y., Wobeser, G., Newstead, J. D. (1984). Acute pathological effects of inorganic mercury and copper in gills of rainbow trout. Vet. Pathol. 21.93-101

Daye, P. G., Garside, E. T (1976). Histopathologic changes in surficial tissues of brook trout, Salvelinus fontinalis (Mitchill), exposed to acute and chronic levels of pH. Can. J. Zool. 54: $2140-2155$

Eddy, F. B. (1982). Osmotic and ionic regulation in captive fish with particular reference to salmonids. Comp. Biochem. Physiol. 72B; 125-141

Fischer, T. (1984). Licht- und elektronenmikroskopische Untersuchungen an Kiemen und Pseudobranchie der Goldorfe (Leuciscus idus L.). VMD thesis, Univ. of Munich 
Fischer-Scherl, T., Hoffmann, R., Schmitt, P., Lehmann, R. (1986). Einfluß der Gewässerversauerung auf die Fischfauna in bayerischen Fließgewässern. Fischer und Teichwirt 4: 101-105

Hughes, G. M., Morgan, M. (1973). The structure of fish gills in relation to their respiratory function. Biol. Rev. 48 : $419-475$

Karlsson, L. (1983). Gill morphology in the zebra fish, Brachydanio rerio (Hamilton-Buchanan). J. Fish Biol. 23: 511-524

Karlsson-Norrgren, L., Björklund, I., Ljungberg, O., Runn, P. (1986). Acid water and aluminium exposure: experimentally induced gill lesions in brown trout, Salmo trutta L. J. Fish Dis. 9: 11-25

Karnaky, K. J. (1980). Ion-secreting epithelia: chloride cells in the head region of Fundulus heteroclitus. Am. J. Physiol. 238, R 185-198

Last, F. T., Likens, G. E., Ulrich, B., Walløe, L. (1980). Acid precipitation - progress and problems. Conference summary. In: Drabløs, D., Tollan, A. (eds.) Proc. int. Conf. Ecol. Impact Acid. Precip. Sandefjord, Norway, SNSF project, Oslo-Ås, p. 10-12

Laurent, P., Hōbe, H., Dunel-Erb, S. (1985). The role of environmental sodium chloride relative to calcium in gill morphology of freshwater salmonid fish. Cell Tissue Res. 240: 675-692

Lehmann, R., Schmitt, P., Bauer, J. (1985). Gewässerversauerung in der Bundesrepublik Deutschland. In: Bundesforschungsanstalt f. Landeskunde und Raumordnung, Bonn, Heft 10: 893-922

Leino, R. L., McCormick, J. H. (1984). Morphological und morphometrical changes in chloride cells of the gills of Pimephales promelas after chronic exposure to acid water. Cell Tissue Res. 236: 121-128

Lock, R. A. C., van Overbeeke, A. P. (1981). Effects of mercuric chloride and methylmercuric chloride on osmoregulatory function of the gills in rainbow trout, Salmo gairdneri Richardson. Comp. Biochem. Physiol. C. Comp. Pharmacol. 68: 151-159

Mallat, J. (1985). Fish gill structural changes induced by toxicants and other irritants: a statistical review. Can. J. Fish. aquat. Sci. 42: 630-648

Mason, J., Seip, H. M. (1985). The current state of knowledge on acidification of surface waters and guidelines for further research. Ambio 14: 45-51

Mckeown, B. A., Geen, G. H., Watson, T. A., Powell, J. F. Parker, D. B. (1985). The effect of $\mathrm{pH}$ on plasma electrolytes, carbonic anhydrase and ATPase activities in rainbow trout (Salmo gairdneri) and large-scale suckers (Catos- tomus macrocheilus). Comp. Biochem. Physiol. 80A $507-514$

Morgan, M., Tovell, P. W. A. (1973). The structure of the gill of the trout, Salmo gairdneri (Richardson). Z. Zellforsch. 142 $147-162$

Muniz, I. P. (1981). Acidification - effects on aquatic organisms. In: Fazzolare, R. A., Smith, C. B. (eds.) Beyond the energy crisis, opportunity and challenge. Pergamon Press, Oxford, p. A101-A.123

Muniz, I. P., Leivestad, H. (1980a). Toxic effects of aluminium on the brown trout, Salmo trutta L. In: Drablos, D. Tollan, A. (eds.) Proc. Int. Conf. Ecol. Impact Acid Precip., Sandefjord, Norway, SNSF project, Oslo-As, p. 320-321

Muniz, I. P., Leivestad, H. (1980b). Acidification effects on freshwater fish. In: Drablos, D., Tollan, A. (eds.) Proc. Int Conf. Ecol. Impact Acid Precip., Sandefjord, Norway SNSF project, Oslo-Ås, p. 84-92

Packer, R. K. (1979). Acid-base balance and gas exchange in brook trout Salvelinus fontinalis exposed to acidic environments. J. exp. Biol. 79: 127-134

Pärt, P., Lock, R. A. C. (1983). Diffusion of calcium, cadmium and mercury in a mucous solution from rainbow trout Comp. Biochem. Physiol. 76C: 259-263

Peters, G., Hong, L. Q. (1985). Gill structure and blood electrolyte levels of European eels under stress. In: Ellis, A. E. (ed.) Fish and shellfish pathology. Academic Press, London, p. 183-196

Randall, D. J., Perry, S. F., Heming, T A. (1982). Gas transfer and acid/base regulation in salmonids. Comp. Biochem. Physiol. 73B: 93-103

Rosseland, B. O. (1980). Physiological responses to acid water in fish. 2. Effects of acid water on metabolism and gill ventilation in brown trout, SaImo trutta L, and brook trout, Salvelinus fontinalis Mitchell. In: Drabløs, D., Tollan, A. (eds.) Proc. Int. Conf. Ecol. Impact Acid Precip., Sandefjord, Norway, SNSF project, Oslo- $\AA$ s, p. 348-349

Ultsch, G. R., Gros, G. (1979). Mucus as a diffusion barrier to oxygen: possible role of $\mathrm{O}_{2}$ uptake at low pH in carp (Cyprinus carpio) gills. Comp. Biochem. Physiol. 62A: 685-689

Ultsch, G. R., Ott, M. E., Heisler, N. (1981). Acid-base and electrolyte status in carp (Cyprinus carpio) exposed to low environmental pH. J. exp. Biol. 93: 65-80

Wieting, J., Lenhart, B., Steinberg, Ch., Hamm, A., Schön, R. (1984). Zusammenfassende Bewertung und Empfehlungen. In: UBA (Umweltbundesamt) (ed.) Gewässerversauerung in der Bundesrepublik Deutschland. Materialien 1/84. Erich Schmidt Verlag, Berlin, p. 450-462 